Insight

\title{
Perceiving and Responding to Gradual Landscape Change at the Community Level: Insights from a Case Study on Agricultural Abandonment in the Black Forest, Germany
}

\author{
Claudia Bieling ${ }^{I}$
}

\begin{abstract}
How is gradual landscape change perceived and dealt with at the community level? Based on a case study approach, this question is investigated with regards to agricultural abandonment and the subsequent expansion of forests in the Black Forest, Germany. In the case presented, local residents' perception of incremental landscape change does not correspond with a survey on biophysical features of landscape change, but rather focuses on visible effects and exhibits considerable time lags. Facing the same problem, local responses to change in two similarly structured and almost adjacent communities contrast strongly in character and outcomes. I conclude that local perceptions of change as well as specific community identities need to be taken into account in landscape management and policy. The promotion of specific examples of well-performing community-based management strategies, preferably by those people directly involved, should be considered as a particularly valuable dissemination tool.
\end{abstract}

Key Words: adaptive comanagement; agricultural abandonment; communities; forest transition; landscape perception; marginal areas; response strategies

\section{INTRODUCTION}

\section{Landscapes as social-ecological systems in change}

Landscapes can be regarded as social-ecological systems (SES). Although rooted in different scientific communities, the concepts of landscape and SES share strong similarities (Kirchhoff et al. 2012). A fundamental common basis is that both point to a coevolutionary interrelationship between the natural and the human realm. A SES is defined by its elements and processes that act at various spatial and temporal scales. In terms of the spatial focus of study, the landscape concept applies a more specific perspective than the SES approach (Stenseke et al. 2012). According to the European Landscape Convention (Council of Europe 2000) definition, a landscape is "an area, as perceived by people, whose character is the result of the action and interaction of natural and/or human factors". Consequently, landscape research focuses on the spatial scale at which human perception allows for the notion of a specific type of interrelationship between nature and culture, i.e., a characteristic landscape.

A core insight from resilience research is that SES inevitably change (Walker and Salt 2006). Like SES in general, landscapes are not static (Antrop 2008, Redman and Foster 2008). Landscape change may be slow and incremental, e.g., as induced by gradual climate change, but also fast and drastic, as in the case of flooding. There is broad scientific consensus that the speed and scale of landscape change in past decades have been unprecedented (Antrop 2004, MA 2005, Jansen et al. 2009). Because of its complex drivers, landscape change may be expressed in a multitude of different forms, ranging from agricultural intensification over urbanization processes to the abandonment of land use (Vos and Meekes 1999, Antrop 2004, Lambin and Geist 2006, Turner et al. 2007).

Regardless of its specific form, landscape change entails changes in the provision of ecosystem services. People at the local level tend to be most directly affected by this (MA 2005). Therefore, landscape change is a key issue for local communities. At the same time, landscapes are predominantly shaped by local residents and their activities such as agriculture, forestry, settlement development, or the establishment of tourism infrastructure. Therefore, local people in their role as land users are key stakeholders as well as key actors in the management of changing landscapes (compare Zhang et al. 2007).

\section{Perceiving and responding to landscape change at the local level}

Finding suitable ways to "navigate" (Berkes et al. 2002) landscape change is an enormous challenge. There are two reasons for this: first, landscapes and corresponding changes exhibit great complexity. Therefore, it is insufficient, but nevertheless common, to address landscape change in a simplistic way (Lambin et al. 2001). In fact, landscape change is the outcome of an interconnected range of various forms of change, most notably economic change, demographic change, changes in livelihood options, and technological change. Second, as Scheffer and Carpenter (2003) point out, although drivers of change are often slow, with the affected system appearing relatively stable, their incremental change may, already at an early stage, induce fundamental shifts that are difficult to reverse. Therefore, recognizing change, e.g., by identifying early-warning signals (Scheffer et al. 2009), at a 
stage at which it is still possible to guide it toward desirable outcomes is both crucial and demanding.

Regarding landscapes, the issue of recognizing change is even more critical because landscapes, and correspondingly their changes, are by definition made 'in the eye of the beholder.' Landscapes result from interplay between natural features and socially stratified perceptions (Zube et al. 1982, Kaplan and Kaplan 1989, Council of Europe 2000). Recognizing landscape change thus follows subjective, context-specific rules and does not necessarily correspond with quantitative assessments of land-cover change. Comparisons of quantitative land-change data with social assessments reveal that there may be considerable differences between the biophysical measures and what is perceived and experienced by affected stakeholders (Zube et al. 1989, Wagner and Gobster 2007). In particular, perceptions focus on visible features (Gobster and Westphal 2004); personal experience and familiarity increases the acknowledgement of change and also focuses attention on specific aspects (Wagner and Gobster 2007), and the views of different social groups may contrast strongly because of varying values and baselines of reference, e.g., for professionals and local residents (Luz 2000). Wagner and Gobster (2007) conclude that perception of landscape change is a fairly complex phenomenon that in turn underlies an equally complex and diversified basis for responses to change.

The resilience framework distinguishes three ways of responding to change (Walker et al. 2004): (1) resilience builds on the capacity to absorb disturbance without the system itself undergoing considerable change. It can therefore be termed a "stability landscape." (2) Adaptation involves enhancing resilience by adapting to changing circumstances, i.e., being able to manage resilience so as to prevent major change. These two response strategies may be impossible or too costly. In this case, responding to change implies, (3) transformation, meaning reorganization into a fundamentally new state. Resilience may be a result of a system's inherent resistance to disturbances, but also an effect of absence of disturbances (apparent stability). The success of adaptation and transformation in terms of desirable outcomes, however, builds on human actors' capacities to respond constructively to change.

This corresponds with the findings of Fabricius et al. (2007) who studied responses to change at the local community level. They state that local-scale strategies for addressing change as well as their appropriateness and success strongly vary. Synthesizing several case studies, the authors distinguish two forms of capacities that are important in responding to change: adaptive capacity describes actors' ability to learn and anticipate, whereas governance capacity refers to suitable ways of exercising power and responsibilities as well as decision making. This results in a threefold typology of communities' responses to ecosystem change: "powerless spectators," i.e., both low adaptive and governance capacity, "coping actors," i.e., adaptive capacity but low governance capacity, and "adaptive co-managers," both high adaptive and governance capacity.

In light of this background and following a case study approach, this paper investigates how gradual landscape change is perceived and dealt with by a local community. Focusing on a municipality in the Black Forest region in southwestern Germany, it explores perceptions of and responses to the phenomenon of agricultural abandonment and subsequent forest expansion. First, long-term land survey data on the municipality's forest area are compared with the local population's perception thereof. In a second step, the responses of local residents to the perceived changes are investigated. In a comparative, but less extensive outlook, these findings are collated with responses in an adjacent community that faces the same developments, but applies a contrasting approach in dealing with them. The analysis of landscape change perceptions and of ways of responding to change finally leads to conclusions for landscape management and policy.

\section{FOREST EXPANSION IN THE BLACK FOREST}

The Black Forest (Fig. 1) is a low mountain range in southwest Germany and part of the federal state of Baden-Württemberg. The region has a temperate climate and stretches about 200 $\mathrm{km}$ from north to south, and approximately $60 \mathrm{~km}$ from west to east. With lowlands at about $230 \mathrm{~m}$ a.s.l. and mountains rising up to almost $1500 \mathrm{~m}$, the Black Forest is characterized

Fig. 1. Location of the Black Forest and the case study areas Bad Rippoldsau-Schapbach and Bermersbach, Germany.

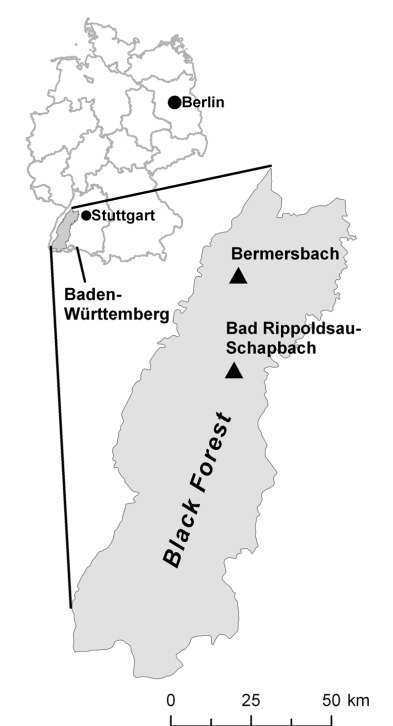


by a highly undulated terrain with deep valleys and steep hillsides. As its almost mythical name suggests, the area is dominated by forests. However, the relation between open spaces and forestland is not, and has never been, stable. In recent decades, as in many other mountainous areas all over Europe (Baldock et al. 1996, Mather 2001), the former common use of grassland for livestock husbandry has been abandoned because of socioeconomic factors. Consequently, the forested area is expanding, partly because of natural succession on abandoned or very extensively used land and partly as a result of active afforestation. As an in-depth analysis of published and internal statistical data of the federal state's Ministry for Rural Areas and Consumer Protection (MLR Baden-Württemberg) reveals (Bieling 2007), the afforestation trend has slowed down in recent years; however, this does not apply to natural reforestation, which will most likely continue or even accelerate because of neighboring effects, that is, higher probability for forest regrowth adjacent to already forested land (see Gellrich et al. 2007).

The effects of forest expansion on biodiversity and the provision of ecosystem services are diverse, strongly contextspecific, and inherently involve trade-offs (MacDonald et al. 2000, Tyrväinen and Tahvanainen 2000, DeFries et al. 2004, Foley et al. 2005, Höchtl et al. 2005, Meyfroidt and Lambin 2011). The main positive effects are the increase of carbon sequestration and the provision of timber. On the other hand, there are various negative effects. In the Black Forest, the land taken over by forest is typically low-intensity grassland sustaining a multitude of rare species. The forests often grow over signs of former agricultural practices and as such a rich cultural heritage diminishes. Loss of the region's typical landscape character and scenic views is bemoaned by local residents as well as tourists. Although the negative effects of forest expansion on tourism have not yet been scientifically confirmed, the potential prospect of these emerging has been generating existential fear among regional actors given that rural tourism is the major economic activity in the region.

For the Black Forest region, the overall effects of agricultural abandonment and subsequent forest expansion are clearly rated as negative. Nature conservation agencies, tourist associations, and most notably the local population worry about a fundamental shift from a mosaic landscape to an almost complete forestland. These public concerns are addressed through policy and regional management; for example, the Common Agricultural Policy of the European Union finances several programs for the promotion of grassland and related land-use practices in marginal areas. Also at the regional scale, there is a range of activities directed at halting forest expansion. Examples include plans at the municipality level that demarcate areas where no further afforestation will be tolerated or marketing initiatives that strive for added value for local livestock husbandry.

\section{MATERIAL AND METHODS}

This research is based on a case-study approach. It focuses on Bad Rippoldsau-Schapbach, a municipality in the northern Black Forest (Freudenstadt district, Fig. 1). Bad RippoldsauSchapbach was a selected investigation area within an interdisciplinary research project on forest expansion in the federal state of Baden-Württemberg, together with four other municipalities (Bieling et al. 2008).

In the course of this project, land-cover change in $\mathrm{Bad}$ Rippoldsau-Schapbach was investigated on the basis of a municipality-wide land survey for three time slices within a period of 123 years. For this, the first cadastral land-use map from 1882 ("Badische Katastervermessung") and aerial photos (ortho-photographs) from 1968 and 2005 were used. The map and the photos were georectified and analyzed in a geographical information system (GIS), using the software ArcGis 9.1 (ESRI 2005). Separate polygon layers were digitized on-screen for each time step and a range of landcover classes. This comprised 10 classes for the historical map (following its legend), and 11 classes for the aerial photos (according to categories distinguishable on-screen like forest, grassland, or settlement). Changes for these land-cover classes were calculated in terms of the changed percentage of the total area investigated. Two maps that designated the forest expansion areas of 1882/1968 and 1968/2005 were created.

Over four years, the perception of the local landscape, its changes, and the activities addressing these changes were studied using mixed methods based in qualitative social research (Table 1). This included various forms of individual and group interviews/discussions, both oral, in person or by phone, and written. Open, semistructured and structured approaches were used. If written results recorded by the participants were not delivered, minutes were taken and, where applicable, written summaries were verified by the participants. These direct approaches initiated by the researchers addressed all relevant stakeholders in the field, that is, experts like the local mayor and representatives of landuse authorities as well as the general public and specifically people involved in local land use, e.g., farmers, forest owners, or people active in the tourism sector. Additionally, other and more indirect forms of acquiring data were used. These included informal phone calls and letters by local residents to the project staff, informal conversations and observations during field work, and the analysis of articles published in the local newspaper, e.g., letters to the editor, reports on the candidates and events in the course of the turbulent election of a new mayor in 2007 in which forest expansion was a major topic. Analysis of data followed the principles of content analysis (Neuendorf 2002).

The ways in which perceived landscape change was dealt with in Bad Rippoldsau-Schapbach were contrasted by those activities undertaken in the community of Bermersbach, part 
Table 1. Data sources used for the analysis of the perception of, and responses to, landscape change in Bad Rippoldsau-Schapbach.

\begin{tabular}{|c|c|c|}
\hline Activity & Participants & Date \\
\hline $\begin{array}{l}\text { Project initiation meeting in Bad Rippoldsau-Schapbach: } \\
\text { guideline-based group interview/discussion }\end{array}$ & $\begin{array}{l}8 \text { (mayor, representatives of local land-use authorities, } \\
\text { local people interested in and/or active in the issue) }\end{array}$ & 08 July 2005 \\
\hline $\begin{array}{l}\text { Public event in Bad Rippoldsau-Schapbach: presentation of } \\
\text { land-use change data for the municipality (GIS-based analysis } \\
\text { of a historical map and aerial photos covering three time slices) } \\
\text { and discussion }\end{array}$ & $\begin{array}{l}\text { Appr. } 50 \text { (interested local public, mayor, representatives } \\
\text { of local land-use authorities) }\end{array}$ & 03 August 2007 \\
\hline $\begin{array}{l}\text { Semistructured telephone or personal interviews on causes of } \\
\text { forest expansion }\end{array}$ & $\begin{array}{l}21 \text { (owners of land in Bad Rippoldsau-Schapbach that, } \\
\text { since the 1970s, has been taken over by forests, as } \\
\text { identified by GIS analysis) }\end{array}$ & October 2006 \\
\hline $\begin{array}{l}\text { Four 1-day workshops on different issues relating to forest } \\
\text { expansion with a mixture of presentations and open as well as } \\
\text { guideline-based group discussions (second workshop took place } \\
\text { in Bad Rippoldsau-Schapbach) }\end{array}$ & $\begin{array}{l}\text { 7-12 (mayor of Bad Rippoldsau-Schapbach and mayors } \\
\text { of three other affected municipalities in the federal state } \\
\text { of Baden-Württemberg, representatives of state land-use } \\
\text { authorities, and project staff) }\end{array}$ & $\begin{array}{l}28 \text { September } 2005 \\
22 \text { August } 2006 \\
20 \text { July } 2007 \\
14 \text { March } 2008\end{array}$ \\
\hline $\begin{array}{l}\text { Structured mailed survey on patterns and causes of forest } \\
\text { expansion and ways to manage it }\end{array}$ & $\begin{array}{l}5 \text { (representatives of local land-use authorities; } 16 \\
\text { representatives of four other affected municipalities in } \\
\text { Baden-Württemberg as a basis for comparison) }\end{array}$ & November 2007 \\
\hline $\begin{array}{l}\text { Informal phone calls and letters to project staff, informal } \\
\text { conversations during fieldwork etc., articles published in local } \\
\text { newspapers (e.g., letters to the editor) }\end{array}$ & Various (citizens of Bad Rippoldsau-Schapbach) & $2005-2008$ \\
\hline
\end{tabular}

of the municipality of Forbach (Rastatt district), which lies approximately $35 \mathrm{~km}$ to the north of Bad RippoldsauSchapbach (Fig. 1). A central player in responses to landscape change in Bermersbach is the local association "Ziegenfreunde Bermersbach" (Friends of the Goats Bermersbach), which fosters open spaces using a broad range of activities. To investigate the situation in Bermersbach, a structured e-mail survey with the head of this association (November 2008, in the course of a state-wide survey of local initiatives for fostering open spaces in marginal regions) and a semistructured telephone interview with another representative (04 April 2011) were conducted. These data were complemented by the analysis of a presentation by the group at a conference (Naturpark Schwarzwald Mitte/Nord 2009) and of the Ziegenfreunde Bermersbach association's web site (http://www.ziegenfreunde-bermersbach.de), which provides detailed information on its operating procedure, e.g., regarding duties of the various forms of members, and activities. Content analysis was again applied for all data acquired in this step.

\section{RESULTS}

\section{Forest expansion and its perception in Bad Rippoldsau- Schapbach}

Bad Rippoldsau-Schapbach is located in a remote valley, ranging in elevation from 370 to $950 \mathrm{~m}$. The municipality is made up of about 35 individual settlements and divided into two greater parts, Bad Rippoldsau and Schapbach, which until 1974 formed separate municipalities and then had to unite in the course of state-wide district reform. As repeatedly underlined in interviews and informal conversations, Bad Rippoldsau and Schapbach have different characteristics, most notably in terms of defining historical events and land ownership structure. The population is currently about 2240 persons, and declining in number (Table 2). Considerable changes have taken place over past decades that strongly correspond with developments across the Black Forest region (Table 2). Regarding the farming sector, roughly $40 \%$ of the principal and part-time farming operations at the end of the 1970s still exist today. Dairy farming in particular was almost completely given up. Tourism is an important source of income for the community; several hotels and small-scale private operations offer beds, moreover, Bad Rippoldsau has a health resort where people can go for relaxation and rehabilitation. However, there is a declining trend evident in this sector. Tourists stay fewer days and beds offered are utilized less than half as often as was the case 25 years ago, resulting in $46 \%$ fewer operations in the tourism sector today.

Bad Rippoldsau-Schapbach is known as the federal state's municipality with the highest proportion of forestland. The analysis of aerial photos (Table 3) from 2005 shows that $91 \%$ of its area is covered by forests, meaning that there are few open spaces aside from the settlements. Further GIS-based analyses of a map from 1882 and of aerial photos from 1968 reveal that this high proportion of forest is due mainly to processes that took place between 1882 and 1968. In the 1880s, forests occupied $79 \%$ of the municipality area. This had increased to $89 \%$ by 1968 . Between 1968 and 2005 there was 
Table 2. Trends in population, farming, and tourism in Bad Rippoldsau-Schapbach (source: Statistisches Landesamt BadenWürttemberg 2012).

\begin{tabular}{llccc}
\hline \hline & & Number (year) & Number (year) & Change in \% \\
\hline Population & & $2535(1980)$ & $2241(2011)$ & -11.6 \\
Farming & Principal farming operations & $11(1979)$ & $5(2007)$ & -54.5 \\
& Part-time farming operations & $87(1979)$ & $35(2007)$ & -59.8 \\
Tourism & Dairy farming operations & $71(1979)$ & $1(2007)$ & -98.6 \\
& Operations offering beds for & $35(1984)$ & $19(2010)$ & -45.7 \\
& tourists & $9.9(1984)$ & $6.2(2010)$ & -37.4 \\
& $\begin{array}{l}\text { Average stay of tourists in days } \\
\text { Capacity utilization of beds } \\
\text { offered in \% }\end{array}$ & $49.2(1984)$ & $21.7(2010)$ & -55.9 \\
\hline
\end{tabular}

a further increase of only $2 \%$. Today, $29 \%$ of the open spaces present in the 1880s still exist. Open spaces that at that time covered more than one-fifth of the community surface today comprise 6\%. Forest expansion areas between 1882 and 1968 covered relatively large parcels, superseding a form of slashand-burn agriculture ("Reutfeldwirtschaft") that has become unprofitable. With forest expansion possibilities almost exhausted, since 1968 only relatively small strips of former grassland adjacent to settlements have converted to forestland.

Table 3. Proportion of forestland and open spaces in Bad Rippoldsau-Schapbach in the years 1882, 1968, and 2005 (\% of the municipality's total area).

\begin{tabular}{lccc}
\hline \hline & 1882 & 1968 & 2005 \\
\hline Forest & $79 \%$ & $89 \%$ & $91 \%$ \\
Open spaces & $21 \%$ & $9 \%$ & $6 \%$ \\
\hline
\end{tabular}

Despite the low rate of forest encroachment since the late 1960s, local residents expressed strong concerns about forest expansion, a phenomenon which, according to the mayor and representatives of local land-use authorities, has arisen in the past two decades. "We want to have a mixture of grassland and forest" was a very common remark in all social-empirical approaches applied. Instead, people described the situation today as being characterized by "too much forest," "the forest is taking over completely," or "we get overwhelmed by forests." People noted in particular that a loss of open spaces and encroaching trees would degrade scenery. This is also related to the current problems in the tourism sector. In interviews as well as informal conversations, several persons considered that tourists would not return because they feel that the landscape has become too dark and lacks scenic views. More specifically, there was agreement that it is important to have spaces for livestock husbandry as "tourists want to see livestock on the pastures." The mayor reported that he had received concrete feedback from several visitors about the diminishing attractiveness of the local landscape. Moreover, one person pointed out that more fog would decrease the attractiveness of the village for tourists, particularly for guests coming for relaxation and rehabilitation. These implied negative effects particularly trouble local residents because tourism is regarded as a substantial current and future source of income.

\section{Responding to forest expansion in Bad Rippoldsau- Schapbach}

Driven by this perception of the problem, forest expansion is a topic of prime importance for the local population. This was reflected, for instance, in the prominence of this issue in the election campaigns of candidates for a new mayor in 2007. A typical statement by one candidate that underlined the existential role of forest expansion and resonated with perceptions on the local level was "If we don't manage to preserve the remaining open spaces, we can forget about our future." Various attempts have been made in Bad RippoldsauSchapbach to secure or even re-establish open land. For at least 10 years, the municipality council has directed efforts toward securing support from the federal state government, for instance to receive high priority funds for fostering agriculture. Direct marketing initiatives, primarily for beef products, have been developed. The mayor introduced repeatedly the idea of establishing a communal grazing community by hiring a specialized shepherd with a flock to use grassland no longer managed by the landowners. As a reaction to local concerns, a federal state institute initiated round table meetings for local stakeholders to facilitate action.

However, all of these approaches did not have a significant impact on the situation. In some cases the efforts were to no avail at all, e.g., in the case of special funds for the municipality. Proposed activities to be pursued at the local level have also been unsuccessful. In particular, local landowners have not supported strategies that would build on cooperation among several persons. For instance, they strongly opposed the idea of allowing their land to be used by a grazing community, even where they were no longer able to use it themselves. They also pressed for funding at the individual farm level instead of considering available funds for the establishment of a winter stable at the community scale. As explained by the mayor and experts on local land use, 
cooperation among landowners and especially across the diverse settlements and the two bigger parts of the municipality has no tradition in the area, is rejected especially by older persons, and therefore conflicts with established local identity. As expressed by one interview partner representing a local land-use authority, "Here in our region, every farmer sees himself as a king on his own little piece of land, and he would rather die than allow somebody else, and especially the neighbor, to do anything with his land."

The effects of other activities remain very limited in space and time, e.g., the round-table meetings did not initiate engagement in the long term, and marketing projects are typically implemented at the level of a single farm. Given the long history of failed attempts to impede forest expansion, people state that local possibilities are exhausted and that financial support in particular now has to be offered from outside the community. "We have done everything we could, now it's time for the state to take action" was a concluding comment made by an attendee of the public event in which data on local forest expansion were presented. "But nobody cares about us, we are a forgotten region" was another comment from this event that expresses the marginalization felt by many local residents. At the same time, people were highly critical of any measures that might diminish local sovereignty. Reducing bureaucracy and surveillance by the state was a central aim stressed by people involved in local land use.

However, in the meantime a new approach for making use of the area's forestland has been established. In 2010, a so-called "Alternative Bear and Wolf Park" opened its doors to visitors (www.baer.de/site2010/). Though they were common in historic times (both Bad Rippoldsau and Schapbach display bears in their municipal coat of arms), for many decades, there have been no wild bears and almost no wolves present in Germany. The idea of the park is to provide old and ill animals that have been mistreated in circuses and animal parks a place to live in largely natural conditions. A 10-hectare forest area was fenced off, offering a spacious habitat for currently six bears and three wolfs. In addition to the aim of animal protection, the park is used for environmental education and as a tourist attraction. The idea for the park was introduced by a nearby resident and then taken up by the municipal council, in spite of protests from local residents who did not want to make space in their village for wilderness and wild animals. Later, it was possible to involve more local stakeholders, and funding was acquired from a private foundation located outside the region ("Stiftung für Bären") as well as from an EU regional development program (LEADER).

Outlook: responding to forest expansion in Bermersbach Bermersbach is located on a mountain ridge, its center at about $410 \mathrm{~m}$, and surrounded by steep valleys. It has approximately 850 inhabitants. Because the community is too small to form an individual administrative unit, it belongs to the municipality of Forbach. For this reason, no specific statistical data is available for Bermersbach. However, statistical data on Forbach indicate a very similar situation in this area to that in Bad Rippoldsau-Schapbach (Statistisches Landesamt BadenWürttemberg 2012); agriculture is in decline, forests are on the increase. With several holiday apartments and rooms available, rural tourism is also important for Bermersbach. As in Bad Rippoldsau-Schapbach, tourists in the Forbach area also stay for shorter periods of time and operations offering beds for tourists have declined in number. Bermersbach has repeatedly gained awards for its characteristic and beautiful appearance.

Local residents report that since the 1950s, with agriculture in strong decline, the community's grassland has been increasingly taken over by trees. Traditional huts, unique to the area and used for storing hay, were also threatened by this development. In the late 1990s, some local people no longer wanted to observe this process and took action. They started with practical work dedicated to clearing woody plants from grassland in one valley (Fig. 2).

Fig. 2. Bermersbach valley (photo: Ziegenfreunde Bermersbach e.V.).

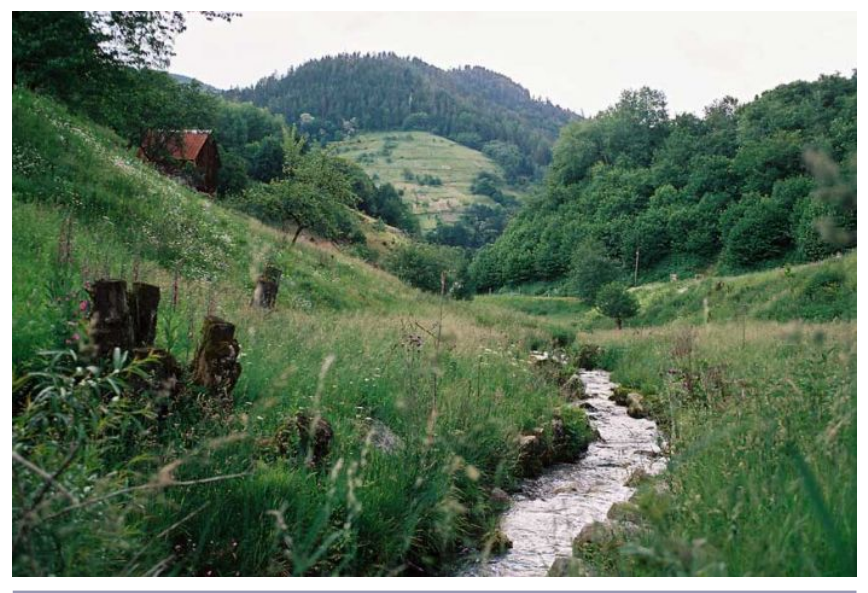

To permanently safeguard the open spaces they organized grazing by a herd of goats. This is arranged by the Ziegenfreunde Bermersbach, or Friends of the Goats Bermersbach association, that was founded in 1998. The association serves as a tool for coordinating activities, providing administrative support and helping to secure state funds, e.g., for investments in the goats' winter stable. The people involved have motivated local residents and opened up ways for them to actively engage. For two weeks annually, each active member of the association is in charge of caring for the goats in their winter stable. They are also required to do at least 20 additional hours of work, for instance building fences or making hay. Other forms of engagement are also possible; the association has initiated a model whereby 
committed individuals, enterprises, and representatives from state authorities can act as personal sponsors for an individual goat, paying, e.g., for veterinary costs. Furthermore, it is possible to act as a general sponsor for the association.

Friends of the Goats Bermersbach has established special offers for different groups. For a broader public they organize an annual open stable day and a summer barbecue party. At these events they manage to sell the complete produce from the year's goat husbandry. A hiking and information trail, where the association also provides guided tours, targets mainly tourists. All offers particularly address young people and serve environmental education purposes. Today in Bermersbach, a herd of more than 100 goats keeps over 60 hectares of land open. Approximately half of the local population is engaged in the association, and related activities are reported as strongly enriching community life. The valued landscape of steep valleys with grassland and hay huts is well tended. On the basis of this success, the initiative is widely recognized and has repeatedly been presented in the media. With local variations, this model is being adopted by several neighboring communities affected by agricultural abandonment.

\section{DISCUSSION}

\section{Framework and methods}

This study is rooted both in the resilience framework and in the research community that formed around the concept of "cultural landscapes." As recently pointed out in a suite of conceptual and case study contributions (Plieninger and Bieling 2012), the connection of these two perspectives has proved to be very fruitful, also in the course of this research. The landscape perspective focused attention on the topic of perceptions. The resilience approach contributed a systematic framework that allowed for the identification of insights aiming at generalization, e.g., by referring to patterns of dealing with change, and particularly highlighted the issue of reorganization in the face of change.

During this research, it proved very helpful to use mixed methods. A combination of biophysical land change data with an extensive social sciences-based investigation of local perceptions thereof was essential for a suitable analysis of the phenomena studied. As described by Brannen (1992), the mixed-methods approach allowed for triangulation of results across different approaches. It thus delivered multiple forms of evidence over a longer period of time and, for the socialempirical part in particular, enabled the researchers to distinguish commonly held views from singular perspectives.

This study presents results from a very specific case that in some respects, e.g., spatial extent, is quite limited. It therefore can be questioned whether transferable insights can be drawn from it. However, as will be demonstrated, the outcomes are very much in line with several other studies from completely different geographical regions and social-ecological contexts.
I thus argue that they go beyond pure hypothesis and in fact provide evidence for recent general insights on landscape change and its management and contribute to the enhancement of these.

\section{Perception of gradual landscape change}

Land survey data shows that for Bad Rippoldsau-Schapbach a shift from a more open to an almost completely forested landscape took place between the 1880s and the late 1960s. However, this shift was perceived considerably later by the local population. Critical voices on forest expansion have emerged only in the past few decades and have become most pronounced in the last 15 years, even though ongoing forest expansion has in fact slowed down to insignificant rates during this period.

In the case of Bad Rippoldsau-Schapbach, I argue that the perception of gradual landscape change displays two characteristics: first, public perception focuses on outcomes visible in the everyday life of local residents, a finding that has also been described by Gobster and Westphal (2004). This becomes evident when comparing the two pictures in Figures 3 and 4 . Although the total area of the municipality's forestland may not have increased significantly, what is visible for people living in the area has changed considerably. Also supported by a study by Hunziker (1995), the turning point for the perception of a regime shift in the context of forest expansion was the establishment of large homogenous forests lacking other interspersed land-use types. This homogeneity becomes apparent not in the first stages of forest encroachment, but rather with the development of adult trees.

Fig. 3. View of Schapbach in the first half of the 20th century (photo date approximately 1940-1950, author unknown).

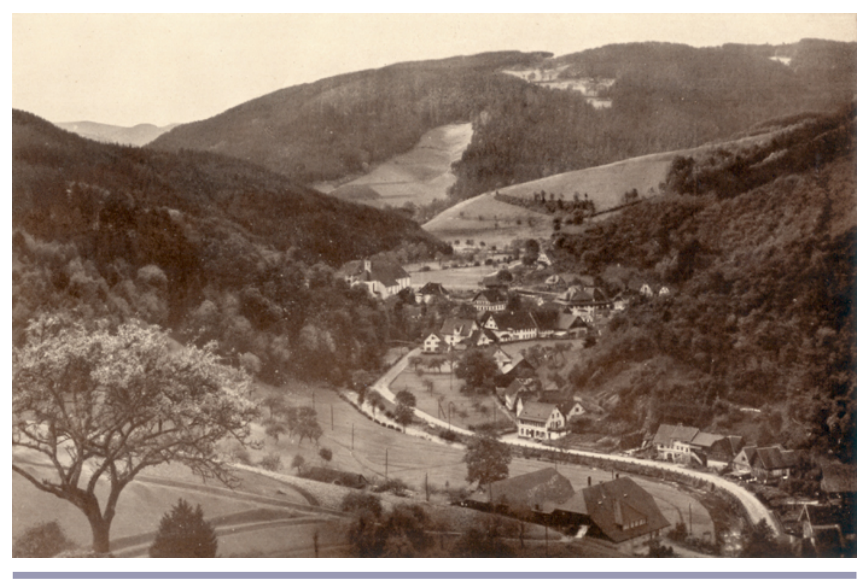

Second, this focus on visible effects, perceived from a specific perspective, i.e., settlements, results in a delay in acknowledging change because forest expansion is not recognized before grown-up trees form a homogenous landscape apparent in everyday life. With undesired changes 
typically manifesting themselves last in areas with high visibility, this effect may also apply to other forms of gradual landscape change. This delay can also be seen as part of an explanation for the discrepancy between the general consensus that rates of landscape change drastically accelerated during the 20th century and change rates as displayed by quantitative land surveys (Schneeberger et al. 2007). Moreover, as Palmer (1997) points out, landscape perceptions in response to change generally tend to be relatively stable.

Fig. 4. View of Schapbach in 2012 (photo: C. Bieling).

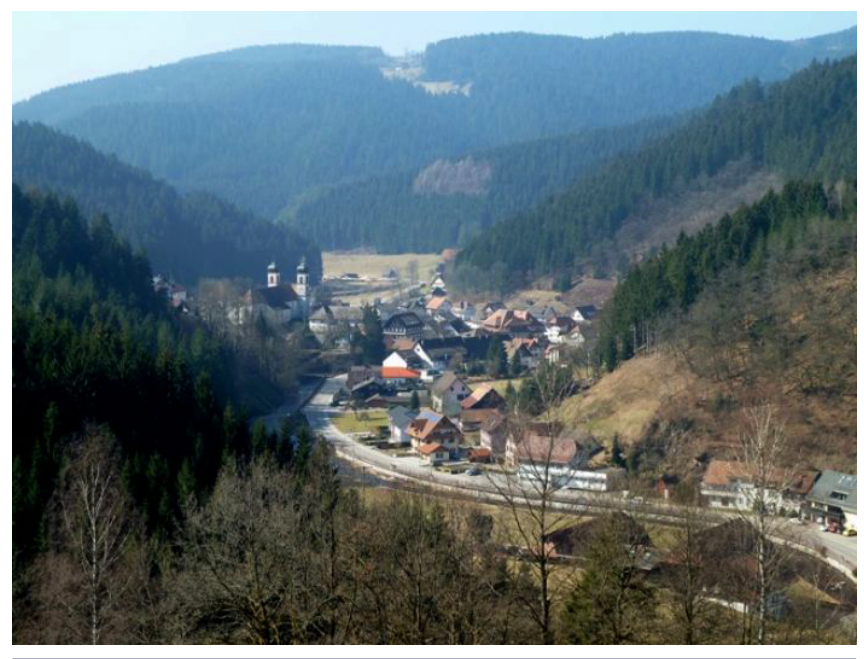

In summary, Bad Rippoldsau-Schapbach had experienced a shift from a mosaic to a forest landscape several decades ago. However, this shift was first acknowledged by the local population following a significant time lag. People are still mentally attached to the prechange conditions of a more open landscape and are only just beginning to reorganize and transform thinking and action.

\section{Responding to change}

Bad Rippoldsau-Schapbach: reinventing the landscape in the face of inevitable change?

In the case of Bad Rippoldsau-Schapbach the development of suitable responses to undesired landscape change is most notably impeded by a lack of cooperation. People do not become active in a way that targets the overarching issue of landscape preservation at the community level, but rather concentrate on individual goals, a scale at which the problem of forest expansion can hardly be solved. Referring to deeprooted notions of a typical individualism in the area that has to be understood in the context of historically dispersed settlement patterns and corresponding social organization, people refuse to work together. Thus, existing options, e.g., in terms of funding, are criticized or not considered because people perceive them to be unsuitable. As such, people are not only constrained by unfavorable circumstances, but also by their tendency to reject the reconsideration of attitudes and opinions. This corresponds largely with the characteristics of both low adaptive and governance capacity as described by Fabricius et al. (2007). With their past activities, local people revealed that they had limited ability or willingness to learn and anticipate and likewise great difficulties in finding suitable ways of exercising power and responsibilities. Therefore, the community may be typified under the category of a "powerless spectator".

However, the newly established bear and wolf park may be seen both as a demonstration of and a trigger for reorganization of thinking and action. The park provides an opportunity for local people to mentally engage with change and to restructure the manner in which they perceive the landscape and attach meaning to it. It manifests and facilitates a reinvention of the landscape as a very attractive and reward-giving largely natural forestland, instead of a human-dominated mosaic of grassland and forests. The leadership and vision of some individuals, first from outside and then from within the community, succeeded in establishing the park and, now that it exists, more and more local residents are in favor of it or even act as supporters. This reconsideration of the local landscape needs time because people are deeply affected in terms of sense of place and identity.

\section{Bermersbach: building alliances to bring about a desired state}

Bermersbach serves as a model of a community that, through building alliances, did not only manage to halt an undesired trajectory of change, but even enhanced local welfare. Three main pillars of this success story can be identified: first, cooperative action and leadership by local people is an essential element. After an initial phase, locals integrated people from outside the village and used public funds so that these external factors now make up an important component. It is important to note, however, that the role of these external factors is determined and shaped by the local actors according to their specific needs. Second, alliances across various spatial levels were built. People from the village drove the efforts, but tourists from abroad, representatives of enterprises in the region, and politicians at the district or the federal state level were also integrated. The project's activities are rooted in this multiscale network. Finally, the association addresses each of the various groups of people in a very specific way, according to their respective capacities and interests. One can help on a regular basis or only for a single event, do physical work or donate money, participate to learn something or simply to enjoy a good party.

These efforts reveal in particular a high governance capacity as described by Fabricius et al. (2007). The flexible character of the activities and structures developed and the focus on raising awareness among young people also demonstrate a 
high level of adaptive capacity. In sum, Bermersbach serves as an example of an "adaptive co-manager" community.

\section{CONCLUSIONS}

Several conclusions for landscape management and policy can be derived from the case study presented. First, because the acknowledgement of change is a prerequisite for responding to it, it is important to realize that public perceptions of landscape change may differ significantly from surveys of biophysical features. This case study's results hereby support several other studies (e.g., Wagner and Gobster 2007) and particularly highlight that a time lag in acknowledging incremental changes and a focus on visual aspects have to be considered. Thus, paying attention to and integrating perceptual factors, most notably by undertaking activities that raise public awareness and foster engagement with the local landscape, should be seen as an important element in successfully managing landscape change (compare also Ryan 2011). Numerous studies, especially in the field of cultural landscape research, show that these activities can be substantiated and triggered by the analysis of subjective narratives represented, e.g., in local literature or landscape painting because they reveal how changing landscapes are perceived over time.

Supporting Fabricius et al. (2007), this study highlights that maintaining links between management and culture is an indispensable element of successful community-based change management. Strategies for responding to change may differ considerably from place to place, even if the background and problem faced seem very uniform. As the rejection of cooperative strategies in Bad Rippoldsau-Schapbach shows, locally adapted strategies that match the specific cultural context and take into account community identity are necessary. This closely corresponds with the conclusions of Crane (2010) based on an African case study. Stewart et al. (2004) likewise show that community identities play a substantial role in envisioning landscape futures and in identifying respective management measures.

It is important to explore possible visions for the future in a creative ways. Successfully responding to change may require the identification of niches and corresponding windows of opportunity for a viable local solution, as in the case of the park for bears and wolfs in Bad Rippoldsau-Schapbach. Typically, these niches are not seen at the outset and they may seem unrealistic or provoke objections. Fostering the creative engagement of people with narratives, e.g., in creative writing events or art performances, can be a very fruitful way to rethink imaginaries and develop new ones (on the role of creative processes and art for transformation and sustainability see Edensor et al. 2009, Kagan 2011). Hence, creativity and vision are important elements of successfully dealing with change, at least for some individuals who can take on a leadership and facilitation role.
This case study indicates that local engagement cannot be substituted by external activities. In the case of $\mathrm{Bad}$ Rippoldsau-Schapbach, attempts to externally trigger local engagement failed to lead to significant outcomes as long as a certain level of motivation and openness for new pathways was absent. However, in line with Berkes (2007), the important role of multilevel networks in Bermersbach indicates that engagement at the local level alone may likewise be insufficient.

In terms of actively fostering community responses through policy and management, this study points to promoting successful examples and to facilitating exchange and learning on viable solutions. The Bermersbach model, which, with local variations, has been adopted by surrounding communities, reveals that an example that proves to work has great potential to inspire people to engage in their own place. This finding is clearly in line with recent studies that highlight the role of face-to-face-based social learning for the diffusion of sustainable land management practices (Schneider et al. 2009). Communication of positive examples, preferably by those people directly involved, should therefore increasingly be used as a particularly powerful element of landscape management and policy.

Responses to this article can be read online at: http://www.ecologyandsociety.org/issues/responses. php/5590

\section{Acknowledgments:}

I thank two anonymous reviewers for their valuable comments. I am grateful to Emily Kilham for language editing and Martin Mantel for designing the map. This contribution is the outcome of two research projects funded by the BWPLUS program of the Federal State of Baden-Württemberg (FKZ BWR 24015) and by the German Ministry of Education and Research $(B M B F)$ under its Social-Ecological Research Program (SÖF, FKZ 01UU0904B). The article processing fee was funded by the German Research Foundation (DFG) and the University of Freiburg in the funding program Open Access Publishing.

\section{LITERATURE CITED}

Antrop, M. 2004. Landscape change and the urbanization process in Europe. Landscape and Urban Planning 67:9-26.

Antrop, M. 2008. Landscapes at risk: about change in the European landscapes. Pages 57-79 in P. Dostal, editor. Evolution of geographical systems and risk processes in the global context. Charles University, Prague, Czech Republic.

Baldock, D., G. Beaufoy, F. Brouwer, and F. Godeschalk. 1996. Farming at the margins: abandonment or redeployment 
of agricultural lands in Europe. IEEP \& LEI-DLO, London, UK.

Berkes, F. 2007. Community-based conservation in a globalized world. Proceedings of the National Academy of Sciences of the United States of America 104:15188-15193. http://dx.doi.org/10.1073/pnas.0702098104

Berkes, F., J. Colding, and C. Folke, editors. 2002. Navigating social-ecological systems: building resilience for complexity and change. Cambridge University Press, Cambridge, UK. http://dx.doi.org/10.1017/CBO9780511541957

Bieling, C. 2007. Behindert die Förderung der Erstaufforstung die Offenhaltung der Landschaft? Das Beispiel BadenWürttemberg. Naturschutz und Landschaftsplanung 39:273-280.

Bieling, C., F. Höchtl, and W. Konold. 2008. Waldzunahme versus Offenhaltung der Landschaft in Baden-Württemberg. Final project report. Institute for Landscape Management, University of Freiburg, Freiburg, Germany. [online] URL: http://www.landespflege-freiburg.de/ressourcen/

\section{BWR24015 Textband.pdf}

Brannen, J., editor. 1992. Mixing methods: qualitative and quantitative research. Ashgate, Aldershot, UK.

Council of Europe. 2000. European Landscape Convention. Treaty Series no. 176, Council of Europe, Strasbourg, France. [online] URL: http://conventions.coe.int/Treaty/en/Treaties/ $\mathrm{Html} / 176 . \mathrm{htm}$

Crane, T. A. 2010. Of models and meanings: cultural resilience in social-ecological systems. Ecology and Society 15(4): 19. [online] URL: http://www.ecologyandsociety.org/vol15/iss4/ $\underline{\operatorname{art} 19 /}$

DeFries, R. S., J. A. Foley, and G. P. Asner. 2004. Land-use choices: balancing human needs and ecosystem function. Frontiers in Ecology and the Environment 2(5):249-257. http://dx.doi.org/10.1890/1540-9295(2004)002[0249:LCBHNA] 2.0.CO;2

Edensor, T. J., D. Leslie, S. Millington, and N. Rantisi, editors. 2009. Spaces of vernacular creativity: rethinking the cultural economy. Routledge, London, UK.

Environmental Systems Research Institute Inc. (ESRI). 2005. ArcGIS 9.1. ESRI, Redlands, California, USA.

Fabricius, C., C. Folke, G. Cundill, and L. Schultz. 2007. Powerless spectators, coping actors, and adaptive comanagers: a synthesis of the role of communities in ecosystem management. Ecology and Society 12(1): 29. [online] URL: http://www.ecologyandsociety.org/vol12/iss1/art29/

Foley, J. A., R. DeFries, G. P. Asner, C. Barford, G. Bonan, S. R. Carpenter, F. S. Chapin, M. T. Coe, G. C. Daily, H. K.
Gibbs, J. H. Helkowski, T. Holloway, E. A. Howard, C. J. Kucharik, C. Monfreda, J. A. Patz, I. C. Prentice, N. Ramankutty, and P. K. Snyder. 2005. Global consequences of land use. Science 309(5734):570-574. http://dx.doi. org/10.1126/science.1111772

Gellrich, M., P. Baur, B. Koch, and N. E. Zimmermann. 2007. Agricultural land abandonment and natural forest re-growth in the Swiss mountains: a spatially explicit economic analysis. Agriculture, Ecosystems \& Environment 118:93-108. http:// dx.doi.org/10.1016/j.agee.2006.05.001

Gobster, P. H., and L. M. Westphal. 2004. The human dimensions of urban greenways: planning for recreation and related experiences. Landscape and Urban Planning 68:147-165. http://dx.doi.org/10.1016/S0169-2046(03)00162-2

Höchtl, F., S. Lehringer, and W. Konold. 2005. "Wilderness": what it means when it becomes a reality - a case study from the southwestern Alps. Landscape and Urban Planning 70:85-95. http://dx.doi.org/10.1016/j.landurbplan.2003.10.006

Hunziker, M. 1995. The spontaneous reafforestion in abandoned agricultural lands: perception and aesthetic assessment by locals and tourists. Landscape and Urban Planning 31:399-410. http://dx.doi.org/10.1016/0169-2046 (95)93251-J

Jansen, J., M. Losvik, and P. Roche. 2009. Vulnerability and resilience of cultural landscapes. Pages 55-66 in $\mathrm{K}$. Krzywinski, M. O'Connell, and H. Küster, editors. Cultural landscapes of Europe: fields of Demeter, haunts of Pan. Aschenbeck Media, Bremen, Germany.

Kagan, S. 2011. Art and sustainability. Connecting patterns for a culture of complexity. Transcript, Bielefeld, Germany.

Kaplan, R., and S. Kaplan. 1989. The experience of nature: $a$ psychological perspective. Cambridge University Press, Cambridge, UK.

Kirchhoff, T., F. S. Brand, and D. Hoheisel. 2012. Cultural landscapes as resilient social-ecological systems: transformation of a classical paradigm or a novel approach? Pages 49-64 in $\mathrm{T}$. Plieninger and $\mathrm{C}$. Bieling, editors. Resilience and the cultural landscape: understanding and managing change in human-shaped environments. Cambridge University Press, Cambridge, UK. http://dx.doi.org/10.1017/CBO9781139107778.005

Lambin, E. F., and H. Geist, editors. 2006. Land-use and land cover change: local processes and global impacts. Springer, Berlin, Germany. http://dx.doi.org/10.1007/3-540-32202-7

Lambin, E. F., B. L. Turner, H. J. Geist, S. B. Agbola, A. Angelsen, J. W. Bruce, O. T. Coomes, R. Dirzo, G. Fischer, C. Folke, P. S. George, K. Homewood, J. Imbernon, R. Leemans, X. Li, E. F. Moran, M. Mortimore, P. S. 
Ramakrishnan, J. F. Richards, H. Skånes, W. Steffen, G. D. Stone, U. Svedin, T. A. Veldkamp, C. Vogel, and J. Xu. 2001. The causes of land-use and land-cover change: moving beyond the myths. Global Environmental Change 11(4):261-269. http://dx.doi.org/10.1016/S0959-3780(01)00007-3

Luz, F. 2000. Participatory landscape ecology - a basis for acceptance and implementation. Landscape and Urban Planning 50:157-166. http://dx.doi.org/10.1016/S0169-2046 (00)00087-6

MacDonald, D., J. R. Crabtree, G. Wiesinger, T. Dax, N. Stamou, P. Fleury, J. Gutierrez Lazpita, and A. Gibon. 2000. Agricultural abandonment in mountain areas of Europe: environmental consequences and policy response. Journal of Environmental Management 59:47-69. http://dx.doi.org/10.1006/ jema.1999.0335

Mather, A. S. 2001. The transition from deforestation to reforestation in Europe. Pages 35-52 in A. Angelsen and D. Kaimowitz, editors. Agricultural technologies and tropical deforestation. CABI, Wallingford, UK. http://dx.doi. org/10.1079/9780851994512.0035

Meyfroidt, P., and E. F. Lambin. 2011. Global forest transition: prospects for an end to deforestation. Annual Review of Environment and Resources 36(1):343-371. http://dx.doi. org/10.1146/annurev-environ-090710-143732

Millennium Ecosystem Assessment (MA). 2005. Ecosystems and human well-being: synthesis. Island Press, Washington, D.C., USA.

Naturpark Schwarzwald Mitte/Nord. 2009. Tourismus braucht Landschaft - Neue Wege zur Offenhaltung der Landschaft im Schwarzwald. Naturpark Schwarzwald Mitte/ Nord, Seebach, Germany. [online] URL: http://www. naturparkschwarzwald.de/shop service/archiv/aktuell/naturparksymposium 2009

Neuendorf, K. A. 2002. The content analysis guidebook. Sage, Thousand Oaks, California, USA.

Palmer, J. F. 1997. Stability of landscape perceptions in the face of landscape change. Landscape and Urban Planning 37:109-113. http://dx.doi.org/10.1016/S0169-2046(96)00375-1

Plieninger, T., and C. Bieling, editors. 2012. Resilience and the cultural landscape: understanding and managing change in human-shaped environments. Cambridge University Press, Cambridge, UK. http://dx.doi.org/10.1017/CBO9781139107778

Redman, C. L., and D. R. Foster, editors. 2008. Agrarian landscapes in transition: comparisons of long-term ecological and cultural change. Oxford University Press, Oxford, UK.

Ryan, R. L. 2011. The social landscape of planning: integrating social and perceptual research with spatial planning information. Landscape and Urban Planning 100:361-363. http://dx.doi.org/10.1016/j.landurbplan.2011.01.015
Scheffer, M., J. Bascompte, W. A. Brock, V. Brovkin, S. R. Carpenter, V. Dakos, H. Held, E. H. van Nes, M. Rietkerk, and G. Sugihara. 2009. Early-warning signals for critical transitions. Nature 461(7260):53-59. http://dx.doi.org/10.1038/ $\underline{\text { nature } 08227}$

Scheffer, M., and S. R. Carpenter. 2003. Catastrophic regime shifts in ecosystems: linking theory to observation. Trends in Ecology \& Evolution 18(12):648-656. http://dx.doi. org/10.1016/j.tree.2003.09.002

Schneeberger, N., M. Bürgi, and P. D. F. Kienast. 2007. Rates of landscape change at the northern fringe of the Swiss Alps: historical and recent tendencies. Landscape and Urban Planning 80:127-136. http://dx.doi.org/10.1016/j.

landurbplan.2006.06.006

Schneider, F., P. Fry, T. Ledermann, and S. Rist. 2009. Social learning processes in Swiss soil protection - the 'from farmerto farmer' project. Human Ecology 37:475-489. http://dx.doi. org/10.1007/s10745-009-9262-1

Statistisches Landesamt Baden-Württemberg. 2012. Strukturund Regionaldatenbank. Statistisches Landesamt BadenWürttemberg, Stuttgart, Germany. [online] URL: http://www. statistik.baden-wuerttemberg.de/SRDB/

Stenseke, M., R. Lindborg, A. Dahlberg, and E. Slätmo. 2012. System or arena? Conceptual concerns around the analysis of landscape dynamics. Pages 80-94 in T. Plieninger and C. Bieling, editors. Resilience and the cultural landscape: understanding and managing change in human-shaped environments. Cambridge University Press, Cambridge, UK. http://dx.doi.org/10.1017/CBO9781139107778.007

Stewart, W. P., D. Liebert, and K. W. Larkin. 2004. Community identities as visions for landscape change. Landscape and Urban Planning 69:315-334. http://dx.doi. org/10.1016/j.landurbplan.2003.07.005

Turner, B. L., II, E. F. Lambin, and A. Reenberg. 2007. The emergence of land change science for global environmental change and sustainability. Proceedings of the National Academy of Sciences of the United States of America 104:20666-20671. http://dx.doi.org/10.1073/pnas.0704119104

Tyrväinen, L., and L. Tahvanainen. 2000. Impacts of afforestation on the scenic value of rural countryside. Pages 141-150 in N. Weber, editor. NEWFOR - new forests for Europe: afforestation at the turn of the century. European Forest Institute, Joensuu, Finland.

Vos, W., and H. Meekes. 1999. Trends in European cultural landscape development: perspectives for a sustainable future. Landscape and Urban Planning 46:3-14. http://dx.doi. org/10.1016/S0169-2046(99)00043-2

Wagner, M. M., and P. H. Gobster. 2007. Interpreting landscape change: measured biophysical change and 
surrounding social context. Landscape and Urban Planning 81:67-80. http://dx.doi.org/10.1016/j.landurbplan.2006.10.019

Walker, B., C. S. Holling, S. Carpenter, and A. Kinzig. 2004. Resilience, adaptability and transformability in socialecological systems. Ecology and Society 9(2): 5. [online] URL: http://www.ecologyandsociety.org/vol9/iss2/art5/

Walker, B., and D. Salt. 2006. Resilience thinking: sustaining ecosystems and people in a changing world. Island Press, Washington, D.C., USA.

Zhang, W., T. H. Ricketts, C. Kremen, K. Carney, and S. M. Swinton. 2007. Ecosystem services and dis-services to agriculture. Ecological Economics 64:253-260. http://dx.doi. org/10.1016/j.ecolecon.2007.02.024

Zube, E. H., S. Friedman, and D. E. Simcox. 1989. Landscape change: perceptions and physical measures. Environmental Management 13:639-644. http://dx.doi.org/10.1007/BF01874970

Zube, E. H., J. L. Sell, and J. G. Taylor. 1982. Landscape perception: research, application and theory. Landscape Planning 9:1-33. http://dx.doi.org/10.1016/0304-3924(82) 90009-0 